\title{
TUJUAN SISTEM INFORMASI MANAJEMEN \\ DALAM MENGAMBIL KEPUTUSAN PENGUSUSAHA KECIL
}

\author{
Fadli Sinaga
}

Prodi Sistem Informasi, Fakultas Sains Dan Teknologi, UINSU

padlisinaga25@gmail.com

\begin{abstract}
$\underline{\text { Abstract }}$
In a Management Information System, namely a Human or Machine System that is integrated in (integrated) to be able to present information that can support as well as operational functions, in Management and making decisions in an organization. Management information systems are guided (integrated) human / machine systems for systems using software, computer hardware and model procedure guidelines as well as management decisions as well as computer databases and management information systems are useful both with closed systems and open systems. The closed computer decision model acts as a counter to be able to calculate more optimal results. And in the open model, the computer can act as a helper in making human needs can calculate, store, and look back, and can also analyze data and so on in design allows in making human decisions in allocating tasks for himself or on the computer. In the Information System, a set of information tools that can be needed by small industries / small entrepreneurs to solve the problems faced. By playing a growing role of information systems in management, finally it can take advantage of the characteristics and specifics of the successful managers of small companies
\end{abstract}

Keywords: Management Information Systems, Hardware, Small Companies.

\section{Abstrak}


Dalam sebuah Sistem Informasi Manajemen Yaitu Sistem pada Manusia dan Mesin yang terintegrasi untuk dapat menyajikan informasi yang dapat mendukung dan juga fungsi operasi, dalam Manajemen dan Mengambilnya dalam putusan pada suatu organisasi.

Sistem informasi manajemen adalah sistem manusia / mesin yang terintegrasi untuk sistem menggunakan perangkat lunak, perangkat keras komputer dan juga pedoman prosedur model dan juga keputusan manajemen serta basis data komputer dan berbasis sistem informasi manajemen berguna baik dengan sistem tertutup maupun juga sistem terbuka. dalam model keputusan tertutup komputer berperan sebagai counter untuk dapat menghitung hasil yang lebih optimal. dan dalam model terbuka, komputer dapat berperan sebagai penolong bagi dalam pengambilan kebutuhan manusia dapat menghitung, menyimpan, dan melihat ke belakang, dan juga dapat menganalisis data dan lain sebagainya dalam desain memungkinkan dalam membuat keputusan manusia dalam mengalokasikan tugas untuk pada dirinya sendiri atau di komputer. Dalam Sistem Informasi pasangan sistem informasi dan di dapat atau diperlukan di dalam industri Pengusaha Kecil ataupun besar dalam menangani dalam permasalahan yang telah di lakukan, berperan tumbuh dari sistem informasi dalam manajemen akhirnya dapat memanfaatkan karakteristik dan khusus dari manajer sukses perusahaan kecil

Kata Kunci : Pentingnya Sistem Informasi Manajemen, Perangkat Keras, bagi Perusahaan Kecil/perusahaan besar

\section{PENDAHULUAN}

Di dalam suatu alat atau sistem

informasi manajemen ataupun SIM

yaitu suatu Informasi dan sering

melakukan suatu pengelolaan dan

transaksi yang diperlukan suatu

Lembaga, dan dapat memberikan support Informasi serta dalam

pengolahan

arti dari fungsi Manajemen dan

dapat mengambil ketetapan. Ketika

suatu pokok sistem informasi dan

seperti sudah muncul sebelum ada

nya Komputer. 
Ketika suatu ok Organisasi yang dapat memerlukan sistem dalam menggabungkan dan juga mengelola serta dapat menyimpan dan membuka serta dapat menghantarkan dalam sistem informasi manajemen tersebut pada bagian wirausaha kecil, Sebab kejadian detonasi penjelasan, begitu redaksi suatu lentuman warga sebuah informasi yang sangat penting dalan suatu kesibukan Kinerja tata kelola/manajemen.

Dikarenakan dalam total pemberitahuan sangat berlebihan, hingga dari pada itu selayaknya dalam urusan pemberitahuan (Informasi) dapat menguasai pertanyaan, dan semestinya orang serta alat juga dapat membangun suatu alat dalam campuran melalui akibat tentunya dapat diselidiki dari berbagai diskusi serta ikatan antar alat serta juga komputer dan masyarakat dalam mengelolanya. Manusia dalam menyimpan keharusan dan mengambil ketentuan jelas layak kalau saja menyetujui manjadi usaha. Masyarakat memproduksi petunjuk (data) dan pengujian data sejenis bentuk supaya ketentuan bisa mengambil melalui makna manusia dalam mengambil keputusan dengan mengutamakan gaya pengelolaan petunjuk sebagai wujud bentuk implementasi bagian wirausaha kecil dalam menerima data aktivitas, mendukung konvensi, memahami kondisi yang tidak teratasi serta dalam Memahami putusan.

\section{STUDI LITERATUR}

Studi literatur yang mana sudah saya kerjakan yaitu dengan bentuk mengangkat beberapa informasi dari jurnal, buku, makalah, karya tulis maupun scripsi tujuan nya untuk membahas tentang Sistem Informasi Manajamen sebagai konsep "Tujuan Sistem Informasi Manajamen dalam mengambil keputusan pengusaha kecil".

\section{HUBUNGAN SISTEM INFORMASI MANAJEMEN}

Melaksanakan Bisnis dalam pekerjakan supaya mampu menjalankan pekerjaan maupun kebiasaan yang dilakukan. Pekerjaan pengelolaan informasi dapat menyertakan Konvensi umum. Teknik arahan manajamen mewujudkan kewajiban dalam menggunakan komputer untuk Memulai dan mengkoordinasikan 
pekerjaan data. Mengaplikasikan sistem informasi sebuah gaya komputer dapat mengutarakan informasi manajemen dalam mengambil ketentuan atau keputusan. Banyak dikalangan masyarakat yang mengkoordinasikan sebuah sistem informasi

Komputer yang sistematis maupun lengkap dalam menyajikan informasi dan membantu dalam menjalankan tugas, Organisasi pengumpulan keputusan dalam menjalankan sistem informasi.

Perangkat lunak dan Perangkat Keras atau yang dimaksud dengan software dan hardware merupakan komputer, dalam mengkonvensi instruktur dalam bentuk data basis.

\section{METODE PENELITIAN}

Sistem Informasi yang memanfaatkan komputer dalam mengakomodasikan manajamen serta mengambil peranan dan alat informasi di dalam organisasi Sistem informasi terbukti ahli mampu memperkuat kemampuan di dalam organisasi. Sistem kemajuan di dalam bidang konsep manajemen dalam pengendalian komputer, harus ada proses rencana sistem informasi manajemen seperti saat ini. Manajemen dapat dipandang sebagai sistem Informasi dalam peningkatan seperti akuntasi Organisasi tentang ketentuan Komputer, sangat lengkap wujud dari gagasan konsep SIM. Pelaksanaan Manajemen yaitu dengan metode ilmiah dan metode tersusun. Analisis penyelidikan manajemen yang umumnya digunakan dengan ringkasan Matematika dalam formal anggaran perlengkapan. Pada kemajuan skarang ini komputer sangat membantu dalam Metode Lembaga yang menekan kan aspek arahan sistem dalam manajemen. Perancangan sistem informasi berkembang dalam konsep Organisasi yang dapat mendukung pemahaman untuk mengkoordinasikan manusia atau mesin.

Berikut ini Metode Penjelasan pokok SIM :

1. Konsep Sistem Informasi adalah mutu pada sistem menambahkan sesuatu dalam penyajian sumbangan dengan waktu.

2. Konsep manusia sebagai pengolah informasi, manusia sebagai pengerjaan kemampuan formasi 
dalam menentukan keterbatasan dari sistem informasi akar dan rancangan

3. Konsep sistem yaitu sistem yaitu suatu sistem, konsep yang perlu dipahami dalam perancangan dan pengembangan

4. Rancangan organisasi dan manajemen sistem informasi si berada di dalam sebuah organisasi dapat dirancang melalui fungsi manajemen

5. Rancangan pengumpulan ketentuan organisasi dalam merancang sebuah sistem informasi manajemen yang bukan mencerminkan rancangan rasional kepada optimasi, tetapi kepada teori perilaku pengambilan keputusan.

6. Anggaran informasi dalam mengambil keputusan untuk mengubah informasi serta menghasilkan nilai yang ditentukan oleh sistem.

\section{KEPUTUSAN ADA 3 TAHAP}

1. Keputusan dapat memerlukan dalam mempelajari kawasan atas kondisi tersebut. Persoalan dapat diperoleh dan diolah, diuji untuk dijadiakan sistem yang dapat mengindentifikasi data.

2. Pemecahan rancangan yang mendatar dalam mengembangkan meliputi proses permasalahan. Dan menghasilkan pemecahan yang layak.

3. Dilaksanakan pemilihan dan memelihara tindakan yang telah di tentukan

Pemilihan dijadikan sebuah proses dalam pengembalian keputusan yang dianggap arus penyelidikan dan organisasi.

Tambahan pada setiap tahap yang hasil nya dapat dikembalikan kepada tahap sebelum nya, dan dimulai dari tahapan tercatat. Unsur pokok pada sebuah proses yang terus-menerus buatan kesukaan barangkali melepaskan substitusi yang dapat di kembalikan ke tahap perencanaan dan menargetkan pecahan.

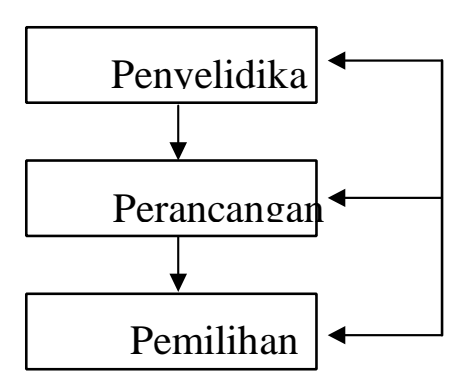

Pada sebuah kekuasaan yang dapat menggerakkan dalam suatu Proses 
pengambilan dalam keputusan juga dapat ada berupa ketidak puasanya atas keadaan yang saat itu dalam Imbalan yang dapat diharapkan dari keadaan yang baru. Pada sebuah kasus ini ketidak puasan dan kekuatan penggerak yaitu dalam penemuan suatu masalah. Peluang dalam imbalan yang dapat di harapkan dari hasul. Keadaan baru untuk menjelaskan proses dalam mengambil keputusan artinya kegiatan penambangan di gerakannya pada suatu tujuan mengganti ( usaha, elemen, anggota dan lain-lain) semenjak bentuk waktu saat ini membuat satu kondisi baru.

Analisis cara tujuan keadaan yang mengakibatkan suatu harapan pencairan tercapai. Dari ahli Rubenstein Dan Haberstroh Ada beberapa model dalam mengambil putusan banyak di laksanakan dengan umpan balik hasil keputusan :

1. Keputusan persoalan atau kebutuhan pengenalan

2. Alternatif dan laporan analisis

3. Alternatif yang ada pemilihan

4. Keputusan pelaksanaan komunikasi

5. Keputusan lanjutan serta umpan balik
Selanjutnya model tertentu tidaklah saling bertentangan titik model Simon yang dasarnya dikatakan dalam pelaksanaan yaitu keputusan yang diperlukan. Model Simon relavansi dalam merancang sebuah sistem informasi di dalam manajamen.

Terdapat 3 tahap hubungan untuk model Simon :

1. Tahap Pemeriksaan hubungan terhadap SIM, fasilitas SIM harus menyediakan cara khusus dalam proses pencarian dan melibatkan pengujian data baik dengan cara yang ditentukan dahulu maupun cara lain.perhatian sistem informasi sendiri harus memeriksa semua data yang menimbulkan suatu permintaan ujicoba pada manusia atas situasi yang jelas tindakan ini terhadap SIM maupun organisasi yang harus menyediakan saluran komunikasi dalam persoalan dan dapat diterima agar dialirkan ke sebuah organisasi.

2. Tahap pembentukan an an dalam pemecahan Harus Memiliki metode-metode keputusan untuk mengolah data SIM, pilihan alternatif harus membantu dalam 
menganalisis metode keputusan yang paling efektif dari hasil rancangan yang disajikan dalam bentuk SIM.

3. Konsep penentuan penafsiran yang telah diambil dari peranan SIM berubah menjadi pengumpulan data.

\section{HASIL DARI PEMBAHASAN}

Keputusan pada sistem sistem komputer yaitu model sistem dengan keputusan diambil, boleh tertutup maupun terbuka.

Keputusan pada sistem tertutup dianggap keputusan terpisah dari masukan tidak diketahui lingkungan :

1. Tiap-tap perangkat anggota penukaran segala dampak akibat nya.

2. Anggota menguasai (sistematis, tautan)

Dapat harus melaksanakan rangkaian kebutuhan.

3. Keuntungan pergantian dan memajukan suatu, apabila keuntungan, daya tampung pemasaran.
Mungkin suatu rancangan sistem ketetapan tertutup jelas dianggap rasional secara logika dalam menguji bentuk dalam pengambilan ketetapan yang di maksud dengan model sistem keputusan tertutup, dan keputusan terbuka melihat berbagai satu Lingkungan yang rumit.

Objektivitas suatu giliran proses "keputusan" kemudian dipengaruhi oleh daerah.

Objektivitas dalam mengambil ketetapan dinggap tidak logis.

Sebagai untuk memperhatikan objektivitas batas yang dikemukakan oleh latar belakang, sudut pandang atas alternatif, kemampuan menangani sebuah model keputusan,dan kemampuan ini dapat menangani suatu model keputusan yang lebih baik.

Kegagalan dalam model tertutup bertujuan yang telah didefinisikan secara baik maka model terbuka serupa dengan sebuah tingkatan aspirasi yang artinya bahwa dapat berubah bila pengambilan keputusan dapat menerima bila ada tujuan. Pengambilan keputusan dibagi menjadi 3 model yaitu tanggapan keputusan tertutup maupun terbuka: 
1. Hasil yang bukan diketahui PERBANDINGAN DALAM segala substitusi.

PENGAMBILAN KEPUTUSAN

2. Memadai penelusuran sebagai kategori untuk menetapkan kurang lebih substitusi yang melakukan.

3. Bunyi suatu ketetapan yang melegakan dapat kutip.

Model terbuka adalah dinamis atas suatu urutan pilihan karena tingkat aspirasi dapat berubah sehubung dengan perbedaan antara hasil dan juga tingkat aspirasi.dengan demikian dapat diuraikan lebih lanjut dalam teori keperilakuan dalam pengambilan keputusan.

\section{DESKRIPSI PENGAMBILAN}

\section{KEPUTUSAN}

Satatis Perspektif adalah sebuah bentuk pengambilan ketetapan. Bentuk elastis yang disebut dengan bentuk secara umum yang telah dikembangkan perspektif para ilmuwan, program linear, teori permainan, dan penganggaran modal. Perilaku Deskriptif dijelaskan bahwa perilaku disempurnakan oleh para intelektual yang disebut dengan bentuk. 
pertama yang memuaskan semua ke dalam persoalan.

\section{RELEVANSI KONSEP KEPUTUSAN} TERHADAP PERANCANGAN SIM

SIM berdasarkan komputer berguna baik dalam sistem tertutup maupun sistem yang terbuka. Pada model keputusan tertutup komputer bertindak sebagai sebuah alat yang dapat menghitung dan Bisa menghitung hasil optimum pada model yang Terbuka, pada alat komputer sangatlah membantu dalam pekerjaan manusia dan juga dalam mengambilan keputusan dapat dihitung, serta dapat mencari kembali, dan juga menguraikan Informasi.

Di dalam organisasi suatu membolehkan mengambil keputusan serta mengatur dan juga mengalokasikan tugas-tugas pada dirinya dan atas Laptop.

Ketika perbedaan pemungutan ketentuan akan ketentuan-ketentuan bentuk keyakinan, beserta juga resiko dan ketidak jelasan yang dapat membuktikan fungsi jumlah ragam atau ketentuan kepada sintetik dan pada masing-masing ragam, kebiasaan petunjuk berlainan, dapat menjadikan penyampaian dan memasukkan keputusan dari manusia dalam mengambil keputusan nya yang bukan serupa.

Keputusan manusia dalam mengambil keputusan di dalam organisasi efisiensi relatif dari sebuah pengolahan keputusan bahwa SIM pemrograman yang terbatas dan harsu memprogram sebanyak-banyak nya.

Keputusan tidak dapat sepenuhnya terprogram, karena mungkin program dalam kasus ini peraturan yang telah ditetapkan sebelum dan digunakan sampai pada waktu tertentu dan diserahkan pada seorang pengguna.

Struktur yang dirancang SIM dalam monitor keputusan program untuk monitor ketentuan yang tampaknya tidak dapat memberikan hasil yang sesuai direncanakan.

Manusia menyediakan an-nur informasi yang dapat membantu cara pengambilan ketentuan. Dan permasalahan yang tidak terprogram terulang yang dirancang dengan struktur untuk mempercepat pengolahan data. 
MAKSUD DARI KELEBIHAN

PERUSAHAAN KECIL

secara pasti arti dalam industri kecil masih saja belum ditentukan.

Industri kecil berlandaskan peraturan pokok sebagai berikut:

perdagangan atau jasa di dalam perusahaan kecil tenaga kerja tidak boleh lebih dari 5 orang. Pengusaha kecil dapat mengutamakan kebebasan dalam bekerja. Para atasan tidak ikut campur dengan pengawasan dan keleluasaan. perusahaan kecil inginkan otonomi dalam mewujudkan inisiatif dan ambisi nilai yang dapat sering kali menimbulkan berbagai inovasi serta elastisitas yaitu Salah satu keunggulan nya. Kelebihankelebihan industri kecil dari pada industri besar terdapat mengikuti tautan yang sangat dari pelanggan, Tenaga kerja dan prn-suppli Tautan dalam tenaga kerja industri kecil dapat mampu memenuhi kesukaan langganan melalui khususan atau pengajuan benda dan kualitas serta jasa yang bukan melalui bagianbagian harga atau pemakaian dominan pada total benda yang kebanyakan beraneka.
Sempitnya presentasi beban langsung pada kegiatan pelaksanaan keuntungan menimbulkan pada jumlah kegiatan dapat dilangsungkan dalam efisien pada industri kecil dari pada oleh industri besar.

dalam pengelolaan tertanam pada kerumitan daerah dapat menimbulkan majikan dan pelaksana perusahaan kecil setempat tidak dapat melaksanakan dengan cara khusus untuk menarik minat masyarakat titik dalam perusahaan kecil tidak hanya melaksanakan barang dan jasa, tetapi juga melahirkan karyawannya.

Dari kekuasaan dalam kesempatan mendalami dan mengembangkan kemampuan mereka secara maksimal. Dan mereka menerima kekuasaan juga melaksanakan ketentuan dari melaksanakan bermacam kegiatan. Hak istimewa tersebut dapat menumbuhkan watak bagi ketertarikan gawai mereka. Kecuali industri kecil untuk membentuk tenaga kerja dalam menjadikan bimbingan dari gesit melainkan dapat memotivasi mudah-mudahan ahli dalam menunggangi bakat-bakat karyawan yang berguna. 
Dalam industri (wirausaha) juga melahirkan wujud suatu keleluasaan hak esensial kemanusiaan, adalah tekadnya akan menanggung resiko dan juga dampak bermanfaat / menyusahkan. Menurut dalam industri mandiri mendalami maupun meninggalkannya perusahaan semuanya, bermula dari kecill juga bertumpuk membentuk besar, memperdalam ataupun memperketat dan beruntung atau sia-sia. Dan untung menurunkan dalam modifikasi pembatasan pekan perusahaan kecil yang mengganti pelaksanaan dengan langsung dan mengikuti perubahan dalam ajakan dan aspek serta kepastiannya perusahaan (wirausaha) pun juga dapat memenuhinya secara terburu-buru, pangkat mampu mengubah aspek usaha nya.

Dalam industri kecil yaitu akar gagasan ide pokok dari berbagai ujian, memulai terobosan serta usaha yang baru. Besar beraneka rupa benda dapat melahirkan industri kecil (wirausaha), apabila bagian komputer dapat tadinya pengembangannya yang dapat melakukan oleh perusahaan besar dimana komputer itu juga sebagai alat prosedur berlomba dengan manusia memenuhi dan memperoleh informasii.

\section{KEKURANGAN-KEKURANGAN PERUSAHAAN KECIL}

Ada 3 macam kelemahan industri kecil, adalah dalam tenaga pengerjaan bukan layak, dan upaya Keuangan sangat lemaah juga kekuatan ekonomi rendah.

Pengusah kecil mempunyai Problemproblem antara lain:

1. Rendahnya keahlian

2. Rendahnya ekonomi

3. Tempat kurang tepat

4. Penyimpangan dalam pengerjaan jnventory

5. Keluasan uang distribusi barang

6. Rendahnya angsuran distribusi melaksanakan aktifitas

7. Kelebihan pada pribadi yang berlebihan

8. Peningkatan bukan sesuai konsep

Implementasi tindakan bagi penanggulangan nya :

- Pemahaman dan ketergantungan dalam kemampuan

- Awalan 
- Pola penyusunan

- Pandangan dari pebandingan laba.

- Pemeriksaan

- Alat listrik / elektronik dan bank

- Menuntut ilmu (belajar)

- Uluran tangan berpengalaman

- Perhatikan aspek tempat kenyamanan

Di dalam progres dapat dikembangkan industri biasa saja, dapat menjadikan industri yang luar biasa atau gabungan tidak membebaskan petunjuk Peranana Sistem Informasi manajamen.

Kecuali dalam organisasi, berdasarkan tugas baik menbuat Penataran, wadah mampu membangun yang bersumber dari pembuatan, misalnya lembaga usaha melalui anggota produksi bagaikan penyediaan tempat tinggal dan gawai, tujuan pemecahan permasalahan. Sebuah lembaga dan jasa atau pemerintah harus dapat memiliki anggota bantuan, misalnya dalam sebuah perusahaan perangkat lunak komputer bisa diorganisasikan dan mengikuti komponen lunak atas pesanan, komponen lunak umum dan pemasaran bantuan komputer.

\section{KESIMPULAN}

Masalah-masalah yang dihadapi setelan alat Informasi yang di perlukan oleh industri kecil (wirausaha) Dalam menangani Sistem Informasi Manajamen.

Keistimewaan atau karakteristik dalam pengelolaan Perusahaan kecil (wirausaha) yang berkembang dan sukses dalam peranan Sistem Informasi Manajamen sebagai bertikut:

1. Berambisi (Ambisius) dalam menjalankan pekerjaan

2. Tujuan untuk Berorentasi

3. Percaya diri yang kuat

4. Mandiri tanpa membutuhkan bantuan

5. Anggaran Berorentasi

6. Sangat Rendah hati

7. Fokus dalam mengerjakan pekerjaan

\section{DAFTAR PUSTAKA}

Gordon B, device, 1991, kerangka dasar Sistem Informasi Manajemen, Jilid I, Pustaka Binaman Pressindo Jakarta, 1992, Stuktur dan pengembangan Sistem 
Informasi Manajemen, Jilid I， Roceaty， Ety， dkk， Sistem informasi Pustaka Binaman Pressindo manajemen pendidikan, (Jakarta : PT Jakarta. Bumi Aksara, 2005).

Djumiaarti, Tahun 2008, Buku

Sistem Informasi manajamen, FISIP

Alhempi, Raden Rudi dan Wismar Harianto 2003, "Pengaruh Pelatihan dan Pembinaan terhadap Pengembangan Pengusaha Kecil pada Program Kemitraan Lingkungan”. Media Riset bisnis dan Manajemen Jurnali, Teddy, Tahun 2001. “Analisis Vol, 13, Nomor 1, April 2003.

Gledoh, Sentot Herman, 2001, "Pembinaan dan Pengembangan Usaha Kecil”, Jurnal Manajemen dan Kewirausahaan, Vol, No,1, Maret 2001.

Andriani, Nina dan Zuliyati, 2015, "Faktor-Faktor yang Mempengaruhi Penggunaan Informasi Akuntansi”, (Studi pada UMKM kain Tenun Ikat Troso Jepara
Attaran M. Dan Van Lantar I. (Maret 2001). "Sistem informasi, dari jurnal technology Informasi pustaka”, Diambil pada tanggal 20 Mei 2005 dari http//:proquest.umi.com/pqdweb

Hartono, J. Tahun 2003. Sistem Teknologi Informasi Bisnis, "Pendekatan Strategi Penerbit : jakarta .

Pengaruh Perkembangan Teknologi Informasi Terhadap faktor Akuntansi Manajemen" Jurnal akuntansi dan keuangan”, Vol. 2, No. 2, November, h $127-137$

Davies, Gordoon B. 1994. Sistem Informasi Manajemen, "Tentang Tumpuan konsep, serta peningkatan MC GrawHill, Kogakusha”, Ltd, Tokyo 
